This is a self-archived version of an original article. This version may differ from the original in pagination and typographic details.

Author(s): Eskelinen, Teppo; Lakkala, Keijo; Laakso, Maria

Title: Introduction : Utopias and the revival of imagination

Year: 2020

Version: Accepted version (Final draft)

Copyright: @ Author \& Zed Books, 2020

Rights: In Copyright

Rights url: http://rightsstatements.org/page//nC/1.0/?language=en

Please cite the original version:

Eskelinen, T., Lakkala, K., \& Laakso, M. (2020). Introduction : Utopias and the revival of imagination. In T. Eskelinen (Ed.), The Revival of Political Imagination : Utopia as Methodology (pp. 3-19). Zed Books. https://doi.org/10.5040/9781350225633.ch.001 


\section{Introduction: Utopias and the Revival of Imagination}

\section{Teppo Eskelinen, Keijo Lakkala and Maria Laakso}

Societal utopias have so frequently been pronounced to be dead, that declaring their demise has become something of a cliché. The general mentality of the 1990s led to the majority of laymen and intellectuals alike to assume this assertion as common sense. According to a widely assumed idea, utopias became obsolete as humanity ascended from the era of totalitarian ideologies to the era of liberal capitalist democracies. In this new order characterized by liberty, no human being is forced to adapt to any grand utopian vision imposed by others. Utopias have a long history, for sure; from antiquity on, with the term coined by Thomas More in 1516. But in our era, society would be different.

In this context, it is difficult to avoid mentioning Francis Fukuyama. In 1989, the then deputy director of the US State Department's policy planning staff published an article which achieved a symbolic status: 'The End of History?' Based on Alexandre Kojève's reading of Hegel's philosophy of history and inspired by the collapse of the Soviet bloc, the article proclaimed that history in the sense of fundamental contradictions was over (Fukuyama 1989, 8).

Yet the novelty of Fukuyama's ideas should not be overstated. The exhaustion of utopian energies and political ideas was noted already three decades earlier by Daniel M. Bell (1960). In political theory texts published in the 1980s, the anti-utopian 'postmodern' sentiment of late stage capitalist societies was quite visible. Jürgen Habermas in The New Obscurity (1986) argued, that the modern time-consciousness based on the ideas of progress and revolution had become narrower, along with the horizon of the future (Habermas 1986, 2). Jean-François Lyotard analysed postmodernism as the intellectual condition in which metanarratives of modernism, including utopianism, have been left behind (Lyotard 1984). Two years before Fukuyama's article, Krishan Kumar could already ask: 'Can there be anything more commonplace than the pronouncement that, in the twentieth century, utopia is dead - and beyond any hope of resurrection?' (Kumar 1987, 30). 
Fukuyama's position might be simplifying to the point of ridiculousness, but it signals a sign of the times. This is the societal condition in which it is almost impossible to think of alternatives to liberal democratic capitalism. To abridge Slavoj Žižek $(2009,53)$ : 'Though it is easy to make fun of Fukuyama's notion of the End of History, the majority today is Fukuyamaist. Liberaldemocratic capitalism is accepted as the finally found formula of the best possible society; all one can do is to render it more just, tolerant and so on'.

A pressing question given this condition is, then, what does the belief in this 'finally found formula' do to key political skills, such as reflection, public criticism and political imagination? Can politics retain a sense of meaning if we believe that it has, more or less, arrived at its destination? Any plausible answer will be hardly short of terrifying. An immediate question then arises: Can the skill to imagine other kinds of societies be saved; and if it can, how?

\section{The specificity of absolutist utopias}

It is natural to begin the rehabilitation of utopian thought by analysing the intellectual mechanisms feeding into its demise. Indeed, the withering away of utopias is not only a common mentality, but subject (and partially also an outcome) of thorough theorising. There is no shortage of sophisticated sociology warning us about the dangers of utopian thought. Most importantly, the popular anti-utopian sentiment discussed above is based on the interpretation of utopias as necessarily absolutist utopias. This interpretation is a very particular one, and hardly exhaustive. It approaches utopias as static models, the implementation of which can only take place in the manner of imposing a blueprint upon society. On this basis, it is easy to interpret utopias as signifying nothing but totalitarianism, as opposed to liberty.

Absolutist interpretations of utopias can take a variety of forms. Aspects of absolutist utopias emphasised by different authors are moral monism, holistic methodology and utopias as closed systems.

The critique of utopian thought as moral monism, as opposed to plurality and versatility, is particularly associated with Isaiah Berlin (Berlin 1997a,b). In Berlin's (1997, 5) words, utopias 
assume an objective and coherent, and unavoidably dogmatic, system of 'moral truths'. In such a system, for every genuine moral question there can be only one correct answer, there is a reliable method for finding the correct moral answers, and all correct answers to moral questions are compatible with each other (Berlin 1997a,5). Yet a perfect whole, 'the ultimate solution' (Berlin 1997a, 11) to moral questions, or a 'perfect social harmony' (Berlin 1997b, 191), are conceptually incoherent ideas. A choice between different values is always necessary. 'We are doomed to choose, and every choice may entail an irreparable loss' (Berlin 1997a, 11). No society can realize all values coherently. This, according to Berlin, renders utopias impossible.

The interpretation of utopias as based on a holistic methodology leading to totalitarianism, derives chiefly from the work of Karl Popper. According to Popper, the utopian desire for impossible perfections and this striving for perfection will inevitably cause violence and repression. For Popper, utopianism is a view according to which 'rational political action must be based upon a more or less clear and detailed description or blueprint of our ideal state, and also upon a plan or blueprint of the historical path that leads towards this goal' (Popper 1963, 358). The concept of utopia is thereby associated with social blueprints and thereby with totalitarianism (e.g. Schapiro 1972, 85; Popper 1963, 357-360). The rational organization of the ideal society that Popper calls utopian engineering is inevitably in the hands of few and therefore inclined to violence and totalitarian control. (Popper 1963).

A third interpretation in absolutist fashion is to see utopias as closed and static systems. Ralf Dahrendorf $(1958,116)$ argued, that one structural characteristic of utopias is their uniformity, based on a universal consensus on values and institutional arrangements, and the absence of disagreement and conflict. 'Utopias are perfect - be it perfectly agreeable or perfectly disagreeable - and consequently there is nothing to quarrel about. Strikes and revolutions are as conspicuously absent from utopian societies as are parliaments in which organized groups advance their conflicting claims for power' (Dahrendorf 1958, 116). Utopias might have 'a nebulous past' (ibid.), but they do not have a future. Utopias 'are suddenly there, and there to stay, suspended in mid-time or, rather, somewhere beyond the ordinary notions of time' (ibid.) 
Many other theorists have landed on interpretations similar to those of these canonical authors. John Gray in Black Mass. Apocalyptic Religion and the Death of Utopia $(2007,2)$ claims, that the whole of Western history has been terrorized by utopian projects: 'entire societies have been destroyed and the world changed forever'. J.L. Talmon $(1952,252)$ defines utopia as the 'complete harmony of interests, sustained without any resort to force, although brought about by force'. Hans Achterhuis argues, that as utopias are seen as perfections, utopia sees itself as legitimizing all violence that could potentially be needed in this realization (Achterhuis $2002,160-161)$. All in all, the intellectual discourse on utopian thought has been dominated by thinkers who 'describe utopianism as a one-way ticket to totalitarianism' (Oudenamspen 2016, 43).

This strong association of utopias with totalitarianism can be understood as an intellectual reflection of the traumas of the twentieth century; 'mankind's darkest hour so far'. The rise of totalitarian regimes, two World Wars, atomic bombings, the Holocaust and the Cold War have left the world in a state of 'cosmic pessimism', to paraphrase Krishan Kumar (1987, 380). When imagining alternative societies, quite a few people have in mind something along the lines of George Orwell's $(1949,390)$ Nineteen Eighty-Four: 'If you want a picture of the future, imagine a boot stamping on a human face - forever'. Yet this fear has already become clearly overstated. The accounts of utopias discussed above have, for a good reason, been called 'dystopic liberalism' (Thaler 2018), or works by 'liberalists of fear' (Skhlar 1989)', in reference to their systematic preoccupation (or should we say obsession) with political evil. Saving humanity from totalitarianism has become an obstacle to political progress and imagination, a justification of whatever is wrong in the current society as a lesser evil by definition. Dystopic liberalism allows little role for political progress, limiting it to 'piecemeal social engineering'. Indeed the absolutist approach to utopias, while widely assumed in popular discourse, is far from being the whole truth about utopias. The absolutist position can be contrasted with the 'relationalist' interpretation. Relationalism sees utopias as first and foremost criticisms and counter-images of the present. They do not exist to be attained as such, informing a holistic description of how society should be constructed, but to show that alternatives to the present exist. Like Terry Eagleton $(2009,33)$ phrases, the alternative worlds in utopian fiction are 
devices for 'embarrassing the world we actually have'. In fact, it is very much possible to think of utopia as an epistemological rather than ontological category. Utopian texts can be understood as heuristic tools for social imagination rather than 'architectural' blueprints for an ideal society. We are interested here exactly in this 'critical function' of utopias, or the role of utopias in criticising and relativising the present by showing a radical alternative to it.

The concept of 'utopia', as such, does not carry any absolutist connotations. As a combination of Greek topos (for place), and (depending on the interpretation) ou for general negative or eu for good (or ideal and prosperous) (see Manuel \& Manuel 1979, 1), '(e)utopia' carries the double meaning of no-place/good-place. 'A good place that does not exist' can well be a dream or a criticism, rather than a blueprint.

Because the present is never static, utopian counter-images assume different interpretations at every point in time. The relationship between reality and dynamic utopias therefore constantly changes, rather than reality just approaching a given fixed utopia. Utopias force the readers to reflect on their own topos. In its most general interpretation, the concept of utopia refers to a place that is more desirable than the one we currently inhabit (Suvin 1997, 126-128). For the relationalist, the idea that utopias are about perfection is a crude misunderstanding (see for example Abensour 2008, Claeys 2017).

With the alarm about utopias as totalitarian, we risk losing utopias as tools for reflection and imagination. The loss of this critical function with the demise of utopias is an alarming symptom of our time. What is at stake is not only critical reflection on society, but the very human capability to conceive of a different world. Part of the modern degradation of utopianism has indeed been 'an incremental impoverishment of what might be called Western imagination'. (Jacoby 2005,5$)$. As totalitarian ideas collapsed under the victory of liberal capitalism, we were made to believe that not only communism, but by and large the quest for a better society was over. The association of utopias with totalitarianism then enforces the idea, that there are no existing or even conceivable alternatives to global capitalism (Levitas \& Sargisson 2003, 15). As noted above in the quote by Žižek's, liberal capitalism is taken as a given, and the hope invested in politics is based on an attempt to qualitatively improve this given system. It can be made 
'more just or more tolerant', but no systemic change is possible. This condition is hardly assisted by the current ecological state of emergency, which might make mere survival seem like a hopeful scenario, and a qualitatively better society beyond the horizon of possibility. The point of saving political imagination by fostering utopias also has implications on the relation between utopias and their ostensible opposites. Namely, the opposing counterparts of utopias are typically seen to be dystopias. The word 'dystopia' (a neologism from Greek dis topos - bad place) was used for the first time by John Stuart Mill in 1868 in a speech criticizing government's policy on Irish property (Milner 2009, 827), and today it is widely used for describing the idea of utopia gone astray. But while literary dystopias clearly describe unpleasant realities, instead of being the opposite of utopias, they can well turn out to serve the same function in terms of critical reflection.

Dystopian and utopian imaginaries alike then function as criticisms of the existing society. Both can be interpreted as social dreaming (Sargent 1994), the key point of which is to support the development of imagination through fiction (see Laakso in this volume). Utopias can be dreams of distant places or dreams of the future, but they are essentially social dreams all the same. Similarly, dystopias show alternative worlds for reflecting upon the existing one. Therefore, the opposite of utopias and dystopias alike is rather the inability to dream.

\section{Towards a methodological understanding of utopianism}

The quest for the revival of utopian imagination and uncovering the functions of utopias in totality requires going back to their roots. The discourse and critical use of utopianism is, in any case, a long tradition in Western political and philosophical thought. Utopianism as social dreaming has traditionally had three important manifestations (Sargent 2010, 5; 1994 2-3): Literary utopias (including non-literary narrative and/or fictional utopias like drama), utopian practice (for example experiments in communal living), and social theory. Utopias then vary significantly in form depending on whether we are talking about utopia as a literary genre, a set of counter-practices, or as a specific form of political thought. 
As we approach utopias as a method for fostering political imagination and critical thinking, all these manifestations are present. Further, utopias need to be approached in a strongly relational sense. Even if a utopian society is described in the form of a closed system, it can be approached as thematically open, since it always relates itself to both the society in which it was written in and to the society it is read in. Indeed utopia means philosophically more a method for thinking societal alternatives than it means ontological space.

Further, even when taking distance from utopia (as a noun) it is necessary to focus on the utopian (as an adjective) ${ }^{1}$. Utopianism (or utopian mentality) should be understood as a general orientation or a quality, as opposed to comprehensive imaginary reconstitutions of society (see Levitas 2013). Anything that expresses an orientation or a desire towards a qualitatively better mode of being, can be perceived as utopian. In other words, 'utopia' refers to 'a non-existent society described in considerable detail and normally located in time and space', while 'utopianism' refers to 'social dreaming' (Sargent 1994, 3-7), as noted above. In the quest for reviving political imagination, the most relevant objects of study will rather relate to utopianism, as we seek utopianism in a large number of existing spaces and practices. The main task is then not the reconstruction of any imaginary society, but locating utopian hope in the world around us.

Human beings constantly orient themselves towards a better state of being. For Karl Mannheim, utopian mentality is something that orients towards a new topos from the present, transcends reality and 'breaks the bonds of the existing order' (Mannheim 1979, 173). Leszek Kolakowski defined utopia as 'a state of social consciousness, a mental counterpart to the social movement for radical change in the world' (Kolakowski 1968, 69). In Ruth Levitas' (2010) words, utopias express the 'desire for a better being'. Frank E. Manuel and Fritzie P. Manuel $(1979,5)$ called this desire the 'utopian propensity' which has manifested itself in diverse forms of human experience throughout the history of mankind. This desire, propensity, or in Ernst Bloch's terms 'principle of Hope' (Bloch 1986) can be seen as a core element of any utopia. According to Vincent Geoghegan $(2008,17)$, 'we can speak of a utopian disposition, a utopian

\footnotetext{
${ }^{1}$ Another way to put this distinction is utopian programmes (realization of a new totality) versus utopian impulse found in political theories, philosophy and cultural products (see Jameson 2005, 6).
} 
impulse or mentality, of which the classic utopia is but one manifestation. This impulse is grounded in the human capacity, and need, for fantasy; the perpetual conscious and unconscious rearranging of reality and one's place in it. It is the attempt to create an environment in which one is truly at ease'.

However, there is a given difference between Bloch's principle of Hope and Levitas' 'desire'. According to Levitas, the concept of hope does not include all forms of utopia. Hope would be in vain if there would not be real prospects of the realisation of its object. The concept of desire, however, is less strongly connected to explicit utopias. Human beings can desire even something completely impossible or vaguely directed desires. One can desire a better being even though there is no hope of this desire being fulfilled. In some cases, there is of course, hope for fulfilment of desire, but desire itself is not the same as what is hoped for. The extension of the concept of hope is then narrower than that of desire; yet both are motivating factors for the search for a better society that need to be taken into account.

Another useful distinction on the different ways to understand utopias as method, can be found in Levitas' (2013) Utopia as Method. The Imaginary Reconstitution of Society. Levitas distinguishes analytically three methodological (often intertwined) modes that utopia can take: The architectural, archeological and ontological. Of these three, the architectural mode refers to depictions of a better world, designs of a better society and delineation of the good society, a more or less detailed picture of a desired world. This 'imagining a reconstructed world and describing its social institutions' (Levitas 2013, 197) is the understanding of utopias on which most critics of utopianism base their scepticism.

The approaches closer to our starting point are the archeological and ontological approaches. The archeological mode of utopian method involves identifying utopian elements in what is typically seen as pragmatic or non-utopian. It pieces together utopian elements embedded for example in political programmes and social and economic policies (Levitas 2013, 153). This mode comes close to the so called 'utopian hermeneutics'. This interpretative research orientation aims to find utopian elements in all areas of human culture. This kind of orientation can be found for example in the works of Ernst Bloch (1986), Douglas Kellner (1997) and Fredric 
Jameson (1979). Especially in Bloch's The Principle of Hope (1986), utopian archeology (or utopian hermeneutics) finds utopian, premonitory and prefigurative images of the future from the works of the past and catalogues this utopian surplus from the early Greek philosophers to the present day. Further, the ontological mode of utopian methods means imagining ourselves otherwise. It also entails a judgment about what constitutes human flourishing. According to Levitas $(2013,196)$, the central point of the ontological mode of utopian method 'is that the utopian method necessarily involves claims about who we are and who we might and should be'.

Here, we want to depart from the architectural mode and focus on the latter two. The task is to understand how utopias can be used, how they affect human beings, and most importantly, to find utopian sentiments in various kinds of spaces and places. Utopian elements can be included in political initiatives which are very much part of the everyday political discourse, such as the Universal Basic Income (UBI), for instance (e.g. Bregman 2016). Or they can be found in experimental politics, contentious spaces, or even ostensibly self-evident political concepts. The methodological challenge is to recognize utopian propensities and their relevance when observing them.

\section{Utopianism facilitating transformation}

Yet the point of utopianism is not only to foster imagination. Utopias exist also to facilitate social transformation, even if not in the absolutist sense. Utopia is then not only a method of reflection, but also a method of changing the world. This approach comes close to what Suman Gupta (2001) has called 'rational utopian thinking', being essentially about revitalising 'an effective political will'. Indeed, political imagination cannot be detached from movements for changing the world.

Another way of interpreting utopia as a method for social transformation is to define utopia as a counter-image or 'a compass'. As a counter-image, utopia reflects social problems of its time and generally relativizes the present. The function of utopias as counter-images emphasises their dynamic and relational nature. In the sense of 'a compass', utopias can also be seen to 
provide a direction (and a purpose) for societal change. Erik Olin Wright's (2010) metaphor of the 'socialist compass' highlights the idea that the function of utopias is to provide an idea of the direction into which society should evolve. The metaphor further implies that on the way to a better society, various kinds of detours will be experienced, yet awareness of the general direction remains.

Utopias as counter-images can also be developed into counter-practices that concretely enable doing otherwise here-and-now (on the connection between counter-image and counterpractice, see Lakkala in this volume). In the age of 'capitalist realism' (Fisher 2009), the main function of utopia is not to articulate goals for political programmes or any detailed visions, but to open the present for the possibility of a better being, so that that systemic alternatives become visible again.

This goal can be expressed with the concept of the facilitating function of utopias, as opposed to their critical function. The function of facilitating social change takes place by creating hope and presenting goals for transformative social action. The critical function, on the other hand, enables questioning and criticising the present society (Levitas 2010), but is not directly relevant for transformative movements. Utopias are always critical, yet not necessarily facilitating.

Even within relatively coherent theoretical approaches utopias have been interpreted both as facilitating social change and as functioning as an obstacle to it. For instance within Marxism, Marx and Engels (2004 [1848]) fiercely criticised utopian socialism for preventing social change ${ }^{2}$ (Levitas 2010,6). According to them, utopian socialism 'formed mere revolutionary sects' and built 'castles in the air'. According to their point of view, utopian socialists, while progressive in their own time, became unable to facilitate social movements, as the dynamism of struggle had changed with the passing of time. In a more analytical fashion, Ernst Bloch $(1986,205)$ made a distinction between the 'cold and warm streams' of Marxism. The cold stream of Marxism, as its critical-scientific manifestation, refers to the conditional analysis of the whole historical

\footnotetext{
${ }^{2}$ In a stricter interpretation, Lenin (2004) saw all utopias as harmful because of their necessary detachment from the political class forces: 'In politics utopia is a wish that can never come true - neither now nor afterwards, a wish that is not based on social forces and is not supported by the growth and development of political class forces'.
} 
situation, unmasking of ideologies and disenchantment of metaphysical illusions. The warm stream of Marxism, on the other hand, is the facilitating and mobilizing function, containing the revolutionary enthusiastic emancipatory intention and the societal (socialist) vision.

In his 1967 lecture delivered at the Free University of West Berlin, Marxist philosopher Herbert Marcuse described this function of utopias as follows: 'Utopia is a historical concept. It refers to projects for social change that are considered impossible. Impossible for what reasons? In the usual discussion of utopia the impossibility of realizing the project of a new society exists when the subjective and objective factors of a given social situation stand in the way of the transformation - the so-called immaturity of the social situation. Communistic projects during the French Revolution and, perhaps, socialism in the most highly developed capitalist countries are both examples of a real or alleged absence of the subjective and objective factors that seem to make realization impossible'. (Marcuse 2014, 250).

The function of preventing societal change can be found mainly in the abstract and static forms of utopian thought. Dreaming of abstract utopian worlds can sometimes become an end in itself, negating concrete action. Lewis Mumford $(1922,20)$ called such abstract utopias 'utopias of escape'. According to Mumford $(1922,20)$, a utopia of escape is 'an enchanted island' where one loses the 'capacity for dealing with things as they are'. In contrast, Mumford introduced the notion of the 'utopia of reconstruction'. A utopia of escape leads back to the ego of the utopian thinker, while the utopia of reconstruction orientates towards the outside world and aims to change it. In this book, we strongly emphasise an approach based on the notion of utopia of reconstruction: Utopias exist for social transformation to be possible.

\section{The purpose of this book and the content of chapters}

To be sure, this is not the first contemporary book written on utopias, not even on their methodological aspects (e.g. Levitas 2013, 2010, Wright 2010, Chrostowska \& Ingram 2017, Sargisson 2012, Žižek \& Thompson 2013). Several authors have noted the need to recognize the open, dynamic and reflexive nature of utopias, and generally the need for utopian thought and horizons beyond the existing (liberal capitalist) social order. Our emphasis is on hope and 
imagination, and their value for transformative purposes. Utopianism both requires and fosters an imaginative skill. This skill needs to be practiced if it is to thrive, be challenged in transformative projects and movements, and most importantly be practiced collectively. While imagination might sound like private and directionless daydreaming, transformative imagination is a collective and reflexive skill. Therefore, we want to depart from philosophical accounts of utopias' focuses on conceptual distinctions, and focus on this utopian skill.

This analysis requires using a number of highly diverse examples. Perhaps utopianism is best fostered in counter-practices, as they properly relate to the critical function of utopias. Maybe we need to look at existing expressions of private hope and ask, how could it be collectivised. Perhaps fostering utopian skills is brought about by reflection through dystopian literature, seeing the utopian element in education, or experimental humour. Or maybe we need to study repressed but (proudly) organized social spaces, architecture and the city as manifestations of utopianism, or ostensibly commonplace political concepts. The numerous case studies in the book develop these different approaches and topics.

In this spirit, we want to also emphasise also a departure from the tradition of 'utopian studies', in the sense of locating literary or real utopias and then analysing them. Our concrete aim is to produce social science for social transformation, and utopias function as a vital inspiring and reflexive tools for this purpose. In the spirit of the notion of 'utopia as method', we do not wish to study utopias, but to use them. Utopias are thereby seen primary as functional, rather than as literary products.

The book continues with a theoretical input, analysing the relation between utopias as counterimages and as counter-practices, to reflect on the question of the facilitating potential of utopianism. Written by Keijo Lakkala, the chapter develops further the notion of utopias as critical counter-images and attempts to restate the essence of utopias as critical and facilitating. The chapter shows that utopias can still have dynamic qualities, and be essentially open to the future. The critical function of utopias is further developed in the context of critical counter-practice, in which 'cracks' are actively sought in the existing social order. 
The third chapter continues by analysing the state of utopias today as privatised hope. As noted above, a given desire for a better mode of being is ubiquitous in humanity, yet it can appear in a variety of different forms. Teppo Eskelinen, Keijo Lakkala and Miikka Pyykkönen ask, how this hope has become individualised and backward-looking. This is assisted by an analysis on how hope is invested in self-control fantasies of entrepreneurship and individual escapes and on how the collective imagination turns into a nostalgic mood. The chapter calls for a recollectivisation of hope, and gives some ideas for tools for this recollectivisation.

These more general and diagnostic chapters are followed by case studies. First, based on the development of the concept of the 'anthropology of hope', Inkeri Aula shows how apparently destitute places and spaces can have a utopian orientation - indeed part of the methodological approach of the anthropologist should be to discern and understand such hope, and further to assist in developing utopian aspirations grounded on this hope. Through a case-study of quilombo communities in Brazil with rich observation data, Aula shows how transformative inspiration can be maintained and built.

In the subsequent chapter, Maria Laakso moves to a case of a very different kind, the dystopian novel. Using Margaret Atwood's The Handmaid's Tale as reference point, Laakso shows the relevance of dystopias for social dreaming and thereby political imagination. Further, the article discusses the function on narratives: tThe narrative nature of the literary novel allows the reader to assume the perspective of a resident of an imaginary social reality. The chapter shows that the assets of dystopian fiction to imagination and critical reflection does not depend even on the time of the writing of the dystopia.

The chapter by Olli-Pekka Moisio and Matti Rautiainen takes up yet again a quite different kind of case, education. Education materialises kinds of utopian hopes, articulated in curricula, and is generally an attempt to prepare people for a world that does not yet exist. On this basis, Moisio and Rautiainen discuss education as enabling human realisation. Reflecting on a case study of a Finnish rural school, they show how a school can be informed by hope and a transformative spirit, if tools exist for collective reflection. The ambitions in education can be high, but are rarely achievable by the lone educator. 
After these case studies, the book turns again into toward a more theoretical mode. Jarno Hietalahti's chapter discusses a necessary yet largely overlooked aspect of utopian thought, which is humour. The importance of the topic derives not only from the misunderstanding of utopias as necessarily perfect and thereby dull places, but also from the significance of experimentation. Looking first at the functioning of conservative laughter at utopia and the radical laughter with utopia, Hietalahti proceeds to seek to transcend this distinction with the notion of laughter in utopia, developing an idea of humour functioning on language in which the syntax does not yet make sense to us, being scary and disturbing and thereby opening new social horizons.

Aleksi Lohtaja's chapter continues by discussing architectural utopias and more generally the question of possibility of utopia in architecture. Seen typically as non-utopian and merely material, architecture provides experimental spaces which can also manifest ideas related to transformative aspirations. Comparing accounts on the relationship between architecture, ideology, and utopias, Lohtaja shows how utopian ideas might exist in city-planning projects, where one does not necessarily look for them.

In the final chapter of the book, Teppo Eskelinen discusses democracy and utopias. The point of the piece is to contribute to the discussion on utopianism by showing how an ostensibly commonplace concept such as democracy can entail utopian elements. This requires an understanding on how radical concepts are diluted and stripped of utopian quality within the existing hegemonic framework of political thought. Democracy remains to be transformative, even revolutionary, if understood consistently and without the restrictions currently imposed on it. The author then sketches the starting points of utopian democracy, discusses its current limitations, and suggests ways forward.

Through these numerous case studies and theoretical inputs, the book makes open and tacit contributions towards its purpose: The revival of political imagination through utopianism. Seeing horizons of collective change is indeed a skill, and fostering this skill depends on whether one is tuned to see glimpses of political hope, whether people can come to together to conceive of change and experiment with it, and whether we are critically aware of the 
background of our current social predicament. Varied though the perspectives within this book are, this heterogeneity is part of the experimental approach needed on the way to the revival of the utopian spirit.

\section{References}

Abensour, M. (2008) ‘Persistent Utopia'. Constellations 15 (3), 406-421.

Achterhuis, H. (2002) 'Violent Utopias'. Peace Review 14 (2), 157-164.

Bell, D. (1960) The End of Ideology: On the Exhaustion of Political Ideas in the Fifties. Cambridge, Massachusetts and London: Harvard University Press.

Berlin, I. (1997a) 'The Pursuit of the Ideal'. In H. Hardy \& R. Hausheer (eds.) The Proper Study of Mankind. An Anthology of Essays. London: Chatto \& Windus, 1-16.

Berlin, I. (1997b) 'Two Concepts of Liberty'. In H. Hardy \& R. Hausheer (eds.) The Proper Study of Mankind. An Anthology of Essays. London: Chatto \& Windus, 191-242.

Bloch, E. (1986) The principle of hope, volume 1. London: Blackwell.

Bregman, R. (2016) Utopia for Realists. The Case for A Universal Basic Income, Open Boarders and A 15-Hour Workweek. Amsterdam: The Correspondent.

Chrostowska, S. D. \& Ingram, J. D. (eds.) (2017) Political Uses of Utopia. New Marxist, Anarchist and Radical Democratic Perspectives. New York: Columbia University Press.

Claeys, G. (2017) 'When Does Utopianism Produce Dystopia?' In Z. Czigányik (ed.) Utopian Horizons. Ideology, Politics, Literature. Budapest/New York: Central European University Press, 41-62.

Dahrendorf, R. (1958) 'Out of Utopia: Toward a Reorientation of Sociological Analysis'. The American Journal of Sociology LXIV (2), 115-127. 
Eagleton, Terry (2009) 'Utopia and its Opposites'. In L. Panitchs \& C. Leys (eds.) Socialist register 2000: Necessary and Unnecessary Utopias. Social Register Vol 36, 31-40.

Fisher, M. (2009) Capitalist Realism. Is There No Alternative? Winchester/Washington: 0 Books.

Fukuyama, F. (1989) 'The End of History?' The National Interest 16, 3-18.

Geoghegan, V. (2008) Utopianism and Marxism. Bern: Peter Lang.

Gray, J. (2007) Black Mass: Apocalyptic Religion and the Death of Utopia. London: Allen Lane.

Gupta, S. (2001) Corporate Capitalism and Political Philosophy. London: Pluto Press.

Habermas, J. (1986) 'The New Obscurity: The Crisis of the Welfare State and the Exhaustion of Utopian Energies'. Philosophy and Social Criticism 11 (2), 1-18.

Jacoby, R. (2005) Picture Imperfect. Utopian Thought for an Anti-Utopian Age. New York: Columbia University Press.

Jameson, F. (1979) 'Reification and Utopia in Mass Culture'. Social Text 1, 130-148.

Jameson, F. (2005) Archeologies of the Future. The Desire Called Utopia and Other Science Fictions. London/New York: Verso.

Kellner, D. (1997) 'Ernst Bloch, Utopia, and Ideology Critique'. In J. O. Daniel \& T. Moylan (eds.) Not Yet: Reconsidering Ernst Bloch. London/New York: Verso, pp. 80-95.

Kolakowski, L. (1968) 'The Concept of the Left'. In L. Kolakowski: Towards a Marxist Humanism. Essays on the Left Today. New York: Grove Press.

Kumar, K. (1987) Utopia and Anti-Utopia in Modern Times. Oxford: Basil Blackwell. Lenin, V.I. (2004) Two Utopias. In Lenin Collected Works. Volume 18. Marxists Internet Archive. Retrieved from https://www.marxists.org/archive/lenin/works/1912/oct/00.htm.

Levitas, R. (2010) The Concept of Utopia. Bern: Peter Lang. 
Levitas, R. (2013) Utopia as Method: The Imaginary Reconstitution of Society. New York: Palgrave Macmillan.

Levitas, R. \& Sargisson, L. (2003) 'Utopia in Dark Times: Optimism/Pessimism and Utopia/Dystopia'. In T. Moylan \& R. Baccolini (eds.) Dark Horizons. Science Fiction and the Dystopian Imagination. New York \& London: Routledge. 13-28.

Lyotard, J-F. (1984) The Postmodern Condition: A Report on Knowledge. Minneapolis: University of Minnesota Press.

Mannheim, K. (1979) Ideology and Utopia. An Introduction to the Sociology of Knowledge. London/Henley: Routledge \& Kegan Paul.

Manuel, F.E. \& Manuel F.P. (1979) Utopian Thought in the Western World. Oxford: Basil Blackwell.

Marcuse, H. (2014) 'The End of Utopia'. In D. Kellner \& C. Pierce (eds.) Marxism, Revolution and Utopia. Collected Papers of Herbert Marcuse. London/New York: Routledge, 249-263.

Marx, K. \& Engels, F. (2004 [1848]) 'Manifesto of the Communist Party'. In Marx/Engels Selected Works. Vol. 1. Marxists Internet Archive. Retrieved from https://www.marxists.org/archive/marx/works/1848/communist-manifesto/.

Milner, Andrew (2009) 'Changing the Climate: The Politics of Dystopia'. Continuum: Journal of Media \& Cultural Studies 23 (6), 827-838.

Mumford, L. (1922) The Story of Utopias. New York: Boni \& Liveright.

Orwell, George (1949) Nineteen Eighty-Four. Oxford: Clarendon Press.

Oudenamspen, Merijn (2016) 'In defence of utopia'. Krisis journal for contemporary philosophy $2016(1), 43-62$. 
Popper, K. R. (1963) Conjectures and Refutations. The Growth of Scientific Knowledge. London: Routledge \& Kegan Paul.

Sargent, L.T. (1994) 'Three Faces of Utopianism Revisited'. Utopian Studies 5 (1), 1-37.

Sargent, Lyman Tower (2010) Utopianism. A Very Short Introduction. New York: Oxford University Press.

Sargisson, Lucy (2012) Fool's Gold? Utopianism in the Twenty-First Century. Basingstoke: Palgrave Macmillan.

Schapiro, L. (1972) Totalitarianism. London: The Pall Mall Press.

Shklar, J.N. (1989) 'The Liberalism of Fear'. In N. L. Rosenbaum (ed.) Liberalism and the Moral Life. Cambridge, Massachusetts: Harvard University Press.

Suvin, D. (1997) 'Locus, Horizon, and Orientation: The Concept of Possible Worlds as a Key to Utopian Studies'. In J. O. Daniel \& T. Moylan (eds.) Not Yet: Reconsidering Ernst Bloch. London/New York: Verso, 122-137.

Talmon, J.L. (1952) The Origins of Totalitarian Democracy. London: Mercury Books.

Thaler, M. (2018) 'Hope Abjuring Hope: On the Place of Utopia in Realist Political Theory'. Political Theory 46 (5), 671-697.

Wright, E. O. (2010) Envisioning Real Utopias. London: Verso.

Žižek, S. (2009) 'How to Begin from the Beginning'. New Left Review. 57, 43-55.

Žižek, S. \& Thompson, P. (eds.) (2013) The Privatization of Hope. Ernst Bloch and the Future of Utopia. Durham \& London: Duke University Press 